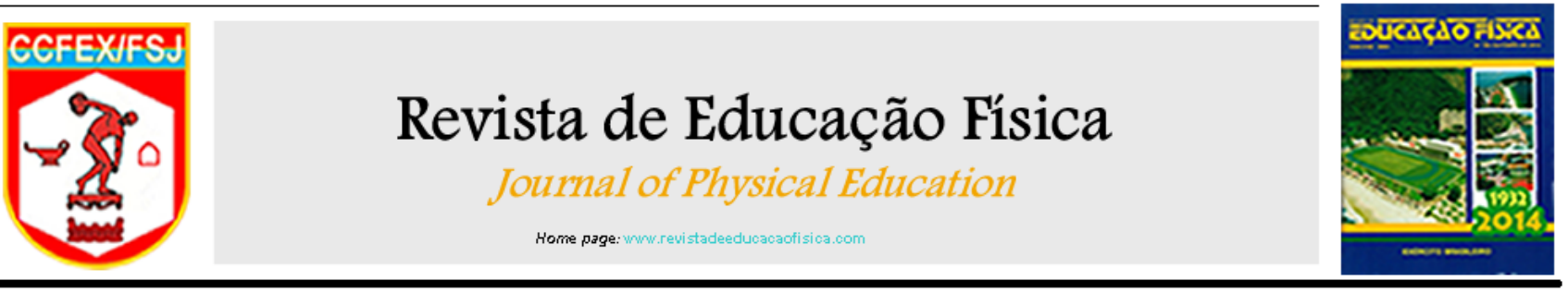

Resumo

\title{
Comparação do impacto gerado com a utilização do calçado militar e do calçado desportivo
}

Daniel Dahmer Kilpp Bsci, Rodrigo Rico Bini PhD

Introdução: No Exército Brasileiro, o calçado fornecido pela cadeia de suprimento é adquirido por meio de licitação, isso faz a necessidade de compra de um material de baixo custo. Isto implicaria que o calçado tenha uma qualidade de material teoricamente inferior ao calçado esportivo.

Objetivo: Comparar o impacto durante a marcha com a utilização de um calçado fornecido pela cadeia de suprimento do Exército e um calçado desportivo renomado no mercado.

Métodos: Dez indivíduos saudáveis caminharam com velocidade controlada em $5 \pm 0,25 \mathrm{~km} / \mathrm{h}$ sobre uma passarela de 11 metros de comprimento, com duas plataformas de força embutidas. Essas permitiram a medição do componente vertical da força de reação do solo. Os ensaios de marcha foram realizados sem o uso de calçados e com um calçado militar (EB 2011, LV Distribuidora LTDA, Brasil) e com um calçado esportivo (Prorunner 17, Mizuno, Japão). Após a medição do peso corporal, com cada um dos modelos de tênis e com os pés descalços, os indivíduos caminharam sobre as plataformas a fim de adquirir 10 tentativas válidas, sendo estas definidas dentro da faixa de velocidade estipulada ( $5 \pm 0,25 \mathrm{~km} / \mathrm{h}$ ) de forma que o contato do pé ocorresse de forma plena com cada plataforma separadamente. Os dados de força de reação do solo foram adquiridos com uma frequência de $1 \mathrm{kHz}$ por ambas as plataformas. Após filtragem digital e normalização pelo peso corporal de cada individuo, a taxa de aceitação do peso foi calculada a partir da maior variação no tempo da força de reação do solo em um intervalo entre $10-90 \%$ do primeiro pico de força.

Resultados: 0 calçado militar apresentou taxa de aceitação do peso $20 \%$ maior do que o calçado desportivo $(\mathrm{p}=0,04)$.

Conclusão: 0 tênis desportivo permitiu uma maior absorção de impacto no contato do calcanhar com o solo em comparação ao tênis militar durante a caminhada. 